Prepared in cooperation with San Miguel County, New Mexico

\title{
Groundwater-Well Data of San Miguel County New Mexico, 1970-2010
}

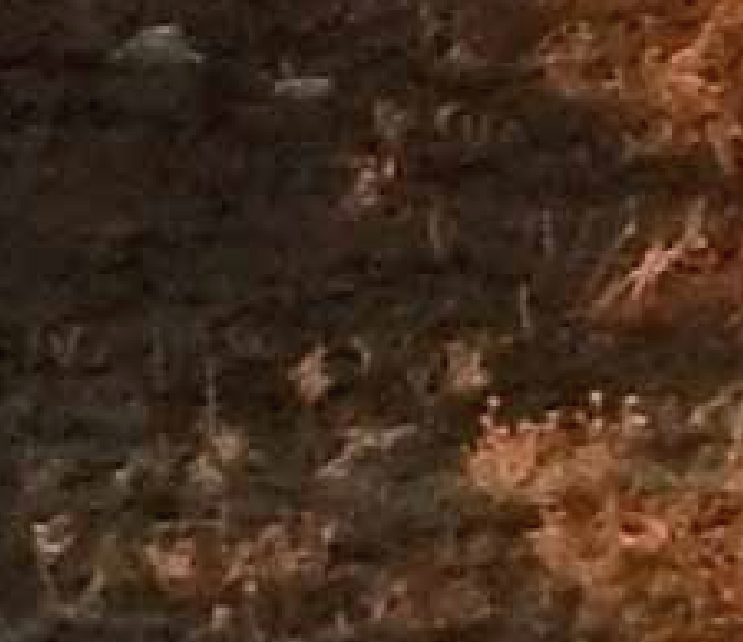

Data Series 686

U.S. Department of the Interior U.S. Geological Survey

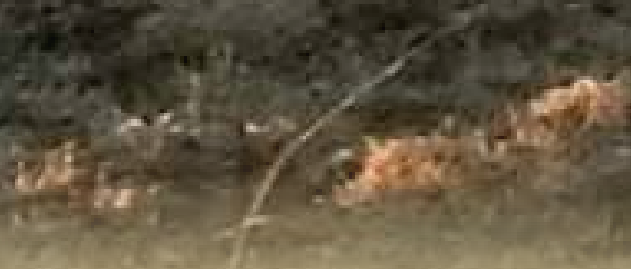





\section{Groundwater-Well Data of San Miguel County, New Mexico, 1970-2010}

By Anne Marie Matherne and Anne M. Stewart

Prepared in cooperation with San Miguel County, New Mexico

Data Series 686 


\section{U.S. Department of the Interior \\ KEN SALAZAR, Secretary \\ U.S. Geological Survey \\ Marcia K. McNutt, Director}

U.S. Geological Survey, Reston, Virginia: 2012

This and other USGS information products are available at http://store.usgs.gov/

U.S. Geological Survey

Box 25286, Denver Federal Center

Denver, CO 80225

To learn about the USGS and its information products visit http://www.usgs.gov/ 1-888-ASK-USGS

Any use of trade, product, or firm names is for descriptive purposes only and does not imply endorsement by the U.S. Government.

Although this report is in the public domain, permission must be secured from the individual copyright owners to reproduce any copyrighted materials contained within this report.

Suggested citation:

Matherne, A.M., and Stewart, A.M., 2012, Groundwater-well data of San Miguel County, New Mexico, 1970-2010: U.S. Geological Survey Data Series 686, 3 p., 2 data tables. 


\section{Contents}

Abstract
Introduction
Purpose and Scope
Methods Used To Acquire and Process Groundwater-Well Data
Limitations of the Data
References Cited

\section{Figures}

1. Griggs and Hendrickson (1951) physiographic areas and New Mexico Office of the State Engineer underground water basin divides in San Miguel County, New Mexico

\section{Tables}

(Available online at http://pubs.usgs.gov/ds/686/.)

1. Information for wells in San Miguel County from the New Mexico Office of the State Engineer New Mexico Water Rights Reporting System database, with depth ranking based on total well depth at time of drilling and grouped by physiographic province as described by Griggs and Hendrickson (1951).

2. Information for wells in San Miguel County, New Mexico, from the U.S. Geological Survey National Water Information System database, with physiographic provinces as described by Griggs and Hendrickson (1951). 


\section{Conversion Factors and Datums}

Inch/Pound to SI

\begin{tabular}{|c|c|c|}
\hline Multiply & By & To obtain \\
\hline \multicolumn{3}{|c|}{ Length } \\
\hline inch (in.) & 2.54 & centimeter $(\mathrm{cm})$ \\
\hline inch (in.) & 25.4 & millimeter $(\mathrm{mm})$ \\
\hline foot (ft) & 0.3048 & meter $(\mathrm{m})$ \\
\hline mile $(\mathrm{mi})$ & 1.609 & kilometer (km) \\
\hline \multicolumn{3}{|c|}{ Area } \\
\hline acre & 4,047 & square meter $\left(\mathrm{m}^{2}\right)$ \\
\hline acre & 0.4047 & hectare (ha) \\
\hline acre & 0.4047 & square hectometer $\left(\mathrm{hm}^{2}\right)$ \\
\hline acre & 0.004047 & square kilometer $\left(\mathrm{km}^{2}\right)$ \\
\hline
\end{tabular}

Vertical coordinate information is referenced to the North American Vertical Datum of 1988 (NAVD 88).

Horizontal coordinate information is referenced to the North American Datum of 1983 (NAD 83). 


\title{
Groundwater-Well Data of San Miguel County, New Mexico, 1970-2010
}

\author{
By Anne Marie Matherne and Anne M. Stewart
}

\begin{abstract}
The hydrologic resources of San Miguel County, New Mexico, are increasingly relied upon to meet growing domestic, livestock, and agricultural needs. The U.S. Geological Survey, in cooperation with San Miguel County, conducted a study during 2010-11 to assess current publicly available information regarding the hydrologic resources of San Miguel County. As part of that study, groundwater-well data from wells located in San Miguel County were acquired from two sources: San Miguel County groundwater-well information archived in the State of New Mexico Water Rights Reporting System online database and groundwaterwell information archived in the National Water Information System of the U.S. Geological Survey. The collected data provide information regarding depth to groundwater and depth of well completions in the context of physiographic features of the county.
\end{abstract}

\section{Introduction}

The hydrologic resources of San Miguel County, New Mexico (fig. 1), are increasingly relied upon to meet growing domestic, livestock, and agricultural needs. Since a study by Griggs and Hendrickson (1951), however, only a few published studies have focused on the hydrogeology and associated surface-water/groundwater interactions within San Miguel County. As a result, there are limited publicly available, fundamental groundwater data upon which to base interpretation of hydrologic processes. The U.S. Geological Survey (USGS), in cooperation with San Miguel County, conducted a study during 2010-11 to assess current publicly available information regarding the hydrologic resources of San Miguel County. As part of that study, groundwater-well data from wells located in San Miguel County were acquired from two sources: San Miguel County groundwater-well information archived in the State of New Mexico Water Rights
Reporting System (NMWRRS) database and groundwaterwell information archived in the National Water Information System (NWIS) database of the U.S. Geological Survey. The collected data provide information regarding depth to groundwater and depth of well completions in the context of physiographic areas of the county.

\section{Purpose and Scope}

This report presents San Miguel County groundwaterwell data acquired from the NMWRRS and the USGS NWIS databases during 2010 and 2011. Methods used to acquire and process the data and limitations of the datasets are presented.

\section{Methods Used To Acquire and Process Groundwater-Well Data}

Digitally archived groundwater-well data were obtained from the NMWRRS database (http://nmwrrs.ose.state.nm.us/ nmwrrs/index.html) and the USGS NWIS database (http:// waterdata.usgs.gov/nwis/gw) during 2010-11. NMWRRSlisted wells (table 1) were reported as drilled between 1973 and 2010, except for a few records for which no drilling date was reported; NWIS-listed wells (table 2) were entered into the NWIS database between 1993 and 2010. According to NMWRRS documentation (New Mexico Office of the State Engineer, 2011a), the NMWRRS compilation of digital groundwater-well data and associated water rights data for San Miguel County had not been completed as of October 2011, when data collection for this report was finalized. NMWRRS groundwater-well data for San Miguel County, summarized in table 1, reflect the status of the NMWRRS database at the time the data were acquired (October 2011). Groundwater-well records available in only paper format were also not included in this report. 


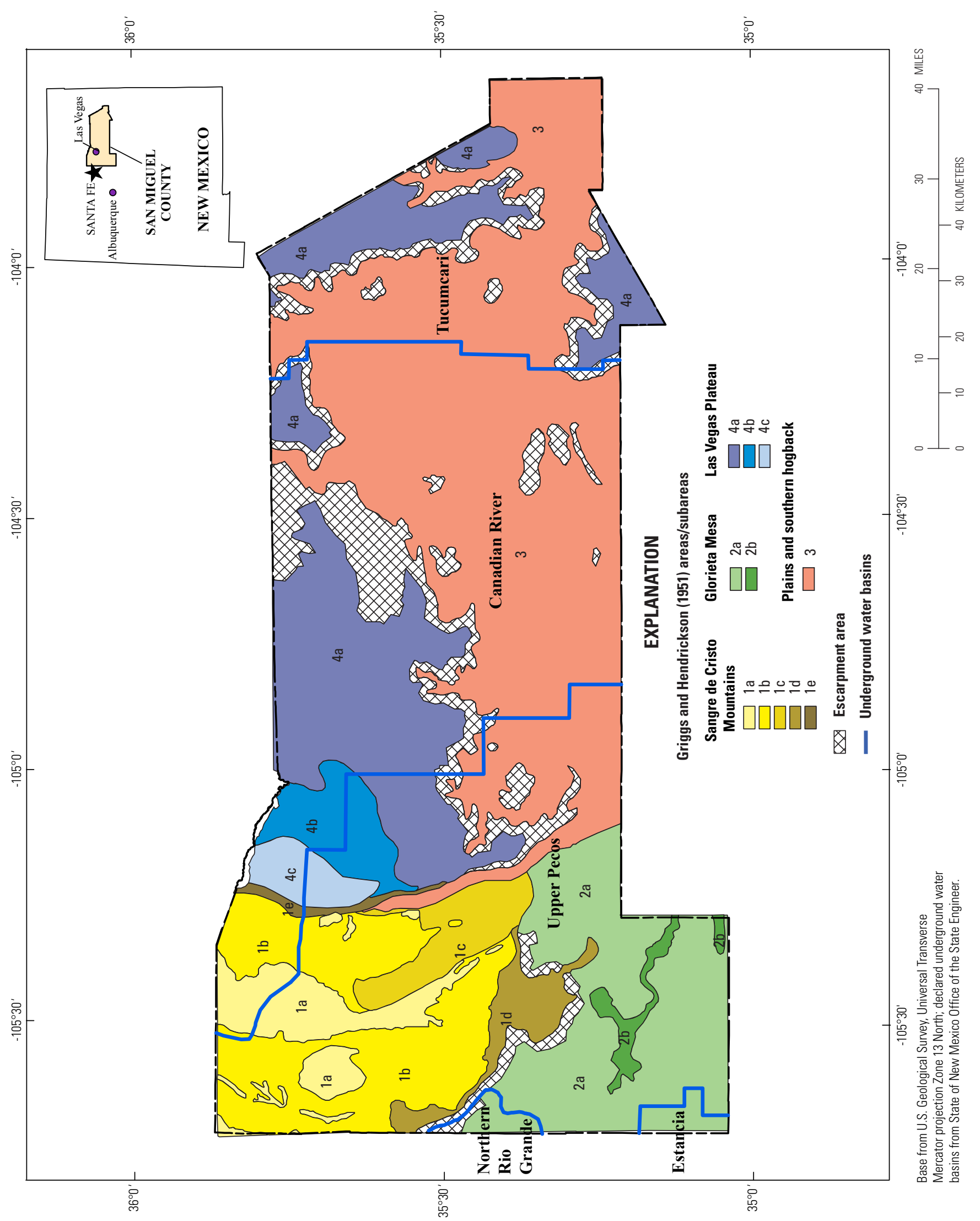

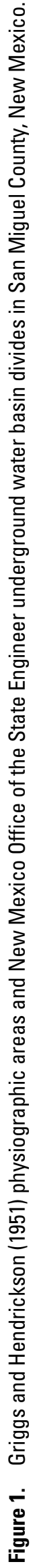


NMWRRS groundwater-well locations were mapped according to reported coordinates (table 1). Seventy-five wells plotted outside of San Miguel County; these wells were removed from table 1, leaving 2,176 well records for San Miguel County. Of these, only 11 did not include data for total well depth.

The USGS NWIS database contained 317 groundwaterwell records for San Miguel County (table 2). Three wells plotted outside of San Miguel County; the associated records were removed from table 2 . Of the 314 remaining wells, 289 were cross-indexed with NMWRRS point-of-diversion (POD) identification numbers. This cross-indexing was performed by the USGS in the mid-1990s on a subset of groundwater wells for which drillers' logs were obtained. POD numbers are reported in table 2 to facilitate cross-referencing with wells in the NMWRRS dataset. Of these NWIS well records, 288 records include identification of the primary tapped aquifers.

Four physiographic areas were identified by Griggs and Hendrickson (1951) within San Miguel County (fig. 1). These four areas include Area 1, with five subareas, comprising the Sangre de Cristo Mountains physiographic area, located in the northwest quadrant of the county; Area 2, with two subareas, comprising the highland portions of the Glorieta Mesa physiographic area, located in the southwest quadrant of the county; Area 3, comprising the plains and southern hogback monocline, located in the central and eastern parts of the county; and Area 4, with three subareas, comprising the Las Vegas Plateau physiographic area, located primarily in the north-central part of the county, with extensions in the northeastern and southeastern parts of the county. Griggs and Hendrickson's (1951) plate delineating physiographic areas and subareas was scanned and registered in a geographic information system project, allowing groundwater-well locations in table 1 and table 2 to be cross-indexed with the respective physiographic areas in which they are located. Detailed descriptions of these physiographic areas and subareas can be found in Griggs and Hendrickson's (1951) report. The location of wells within declared underground water basins (New Mexico Office of the State Engineer, 2011b) (fig. 1) can be evaluated on the basis of reported location coordinates.

\section{Limitations of the Data}

The reliability of groundwater-well locations as reported in the NMWRRS and NWIS databases is a function of the general accuracy of well locations as reported in the original well logs and of the spatial resolution of the reporting system. For both the NMWRRS and the NWIS databases, the original well locations were designated on well drillers' reports by either property owners or well drillers using the Public Land Survey System (PLSS), which is based on township, range, section number, and telescopic divisions of quarter-sections. The PLSS is not mapped within land grants, and wells located within land grants are generally projected to PLSS, which may generate additional estimation errors. The well point locations reported in tables 1 and 2 represent the centers of the smallest reported quarter-section division provided by well drillers in the well logs and so are inherently approximate because they refer to a center point of an area rather than to a point location of a given well. Well locations reported in tables 1 and 2 have been neither field verified nor validated. Ancillary data associated with the well records are presented as derived from the respective databases.

\section{References Cited}

Griggs, R.L., and Hendrickson, G.E., 1951, Geology and ground-water resources of San Miguel County, New Mexico: New Mexico Bureau of Mines and Mineral Resources, Groundwater Report 2, 121 p.

New Mexico Office of the State Engineer, 2011a, Water rights research system, areas abstracted into the database: New Mexico Office of the State Engineer, New Mexico Water Rights Reporting System, accessed on October 3, 2011, at http://www.ose.state.nm.us/PDF/ Maps/WATERS-Abstract.pdf.

New Mexico Office of the State Engineer, 2011b, Underground water basins in New Mexico: New Mexico Office of the State Engineer Water Information, accessed October 15, 2011, at http://www.ose.state.nm.us/PDF/Maps/ underground_water.pdf. 



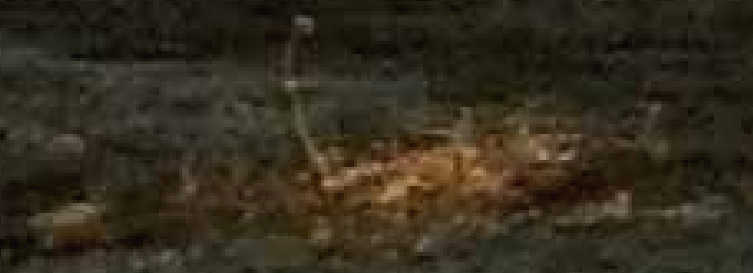

